\title{
Performance Analysis of an Existing BIPV System for Indian Climatic Conditions
}

\author{
Abhishek Ranjan, Swapnil Dubey, Basant Agarwal and G. N. Tiwari* \\ Centre for Energy Studies, Indian Institute of Technology Delhi, Hauz Khas, New Delhi 110016, India
}

\begin{abstract}
In this communication, an attempt has been made for evaluating the performance of an existing BIPV system for Indian climatic conditions, considering four weather conditions ( $a, b, c$ and d type) for five different cities (New Delhi, Bangalore, Mumbai, Srinagar, and Jodhpur) of India. In this paper, first solar radiation is calculated on inclined roof $\left(30^{\circ}\right)$, south, east and west facades $\left(90^{\circ}\right)$ of the building and then fourteen different possible series and parallel combinations of PV integrated air ducts mounted on roof have been considered for the evaluation of thermal and electrical gain.

It is found that, the average electrical efficiency of the system is $9.64 \%$. Annual thermal and electrical gain obtained for the best combination (11 ducts are connected in parallel each having three PV modules) is $13.42 \mathrm{MWh}$ and $4.38 \mathrm{MWh}$ respectively for New Delhi condition. It is a self sustainable system where electrical energy is used for lighting purpose and thermal energy is used for space heating and drying.
\end{abstract}

Keywords: Photovoltaics, BIPV, thermal and electrical energy, solar energy.

\section{INTRODUCTION}

Most of the absorbed solar radiation by solar cells is not converted into electricity and increases their temperature which reduces their electrical efficiency. The photovoltaic (PV) temperature can be lowered by heat extraction with a proper natural or forced fluid circulation. Hybrid photovoltaic/thermal (PV/T) system consists of PV module coupled with heat extraction device, so that it can provide electricity and thermal energy simultaneously. Several theoretical and experimental studies on hybrid PV/T systems have been done by previous researchers. Loferski et al. [1] gave results for a hybrid system with air circulation installed on a residential building, by using two separate one-dimensional analyses compared with test measurements. Bhargava et al. [2] and Prakash [3] have analyzed the effect of air mass flow rate, air channel depth, length and fraction of absorber plate area covered by solar cells (packing factor, PF) on single pass. A parametric study of a PV cladding for building roof and façade was presented by Brinkworth et al. [4].

Hagazy [5] and Sopian et al. [6] investigated a glazed photovoltaic/thermal air system with a single or double pass air heater for space heating and drying. They have developed thermal models for each system. The thermal energy obtained from the glazed PV/T system gets increased along with lower electrical efficiency (due to high operating temperature). An unglazed hybrid photovoltaic/thermal system with a booster diffuse reflector is integrated with the horizontal roof of a building which increases the performance of the system [7]. Murata et al. [8] have developed a new type

*Address correspondence to this author at the Centre for Energy Studies, I.I.T. Delhi, 110016, India; Tel: +91 11 26591258; Fax: +91 1126581121 , 26862037; E-mail: gntiwari@ces.iitd.ernet.in of photovoltaic (PV) module integrated with roofing material (a highly fire-resistant PV tile).

When photovoltaics are integrated into building skin, it is called building integrated photovoltaic system (BIPV). The larger part of the incident solar radiation on the PV elements is converted into sensible heat, which increases temperature of solar cells and reduce the electrical efficiency. Ventilating the cavity behind the PV limits the temperature rise, and the warm air may be used for ventilation pre-heat in winter, or driving natural ventilation in summer. Yang et al. [9] have mentioned that the PV systems can easily be installed on the roof of residential as well as on the wall of commercial buildings as grid-connected PV application. They have investigated the effect of natural ventilation on power output and heat transfer across the air gap between the PV wall and PV roof and studied the energy performance of BIPV system for Hong Kong weather conditions and found that the system can provide about $41 \%$ of electric power for indoor lighting and overall efficiency of the system is about $9 \%$. Zakharchenko et al. [10] have also studied unglazed hybrid PV-thermal systems with a suitable thermal contact between the panel and the collector. Infield et al. [11] have observed that the ventilated facades lead to enhancement of the electrical efficiency of a PV module on account of corresponding low temperature (generally below $45^{\circ} \mathrm{C}$ ).

Drif et al. [12] have mentioned that the grid connected photovoltaic (PV) systems are very popular in industrialized countries and can be considered as the most promising PV application. It is generally recognized that the PV's in building have potential to become a major source of renewable energy in the urban environment as mentioned by Tian et al. [13]. The electrical and thermal performance of PV systems (glass to glass) integrated as a cladding component in the building envelope has been evaluated by Bloem [14]. 
In this paper, performance of existing building integrated hybrid photovoltaic thermal (PV/T) system has been evaluated for Indian climatic conditions by considering four weather conditions for five different cities (New Delhi, Bangalore, Mumbai, Srinagar, and Jodhpur) of India. Fourteen different series and parallel combinations of PV integrated air ducts have been considered for the evaluation of thermal and electrical gain.

\section{CONFIGURATION OF BIPV SYSTEM}

The cross sectional view of working model of building integrated photovoltaic (BIPV) system installed in Hong Kong is shown in Fig. (1a). The total integration area is 55 $\mathrm{m}^{2}$, out of which $11 \mathrm{~m}^{2}$ is located on the vertical east and west façades, $12 \mathrm{~m}^{2}$ on the vertical south façade and remaining $21 \mathrm{~m}^{2}$ is located on the roof of the building. Electricity generated by this system is used for daytime lighting of the building for about $250 \mathrm{~m}^{2}$ floor area in the building, Yang et al. [9].

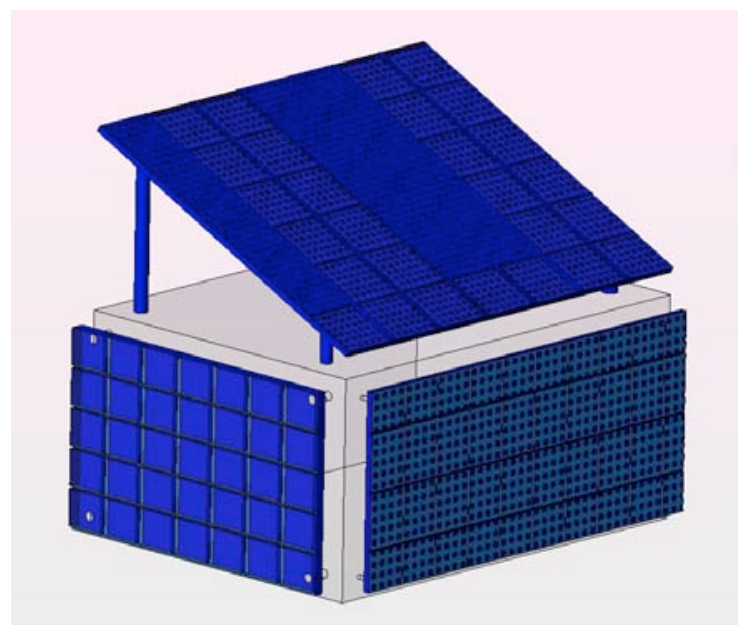

Fig. (1a). 3D representation of the Building integrated photovoltaic system (BIPV).

In this paper, performance of existing BIPV system is evaluated for Indian climatic conditions. Maximum electrical energy gain is obtained from roof integrated PV modules, therefore to increase the electrical efficiency of PV modules and simultaneously for thermal energy gain air duct is integrated with PV modules. Cross sectional view of glass to tedlar type PV module with air duct is shown in Fig. (1b).

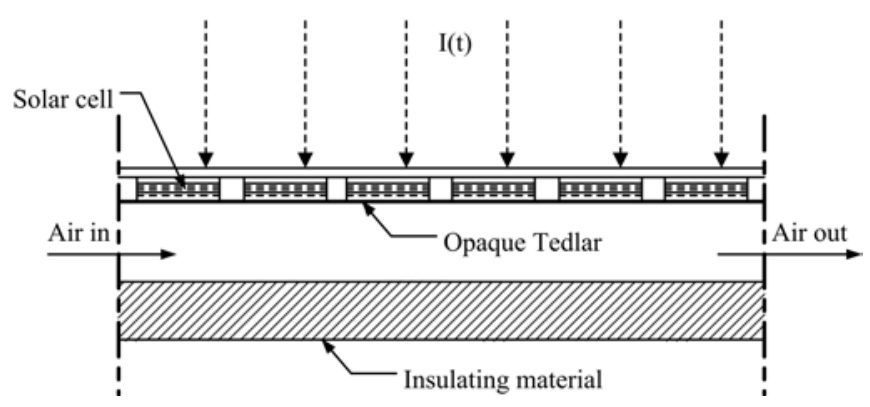

Fig. (1b). Cross sectional view of glass to tedlar PV module with duct.
Total 35 numbers of PV modules are integrated over the roof and fourteen different possible series and parallel combinations of duct have been considered for the calculation of thermal and electrical energy gain. The fourteen combinations are classified as:

(a) Five PV modules on each duct;

1. 7 ducts connected in parallel.

2. 2 ducts connected in series (3 sets) and 1 duct (1 set), all are connected in parallel.

3. 3 ducts connected in series (2 sets) and 1 duct (1 set), all are connected in parallel.

4. 4 ducts connected in series (1 set) and 3 ducts connected in series (1 set), both are connected in parallel.

5. 5 ducts connected in series (1 set) and 2 ducts connected in series (1 set), both are connected in parallel.

(b) Three PV modules on each duct;

6. 11 ducts connected in parallel (1 set) and one duct having 2 PV module, all are connected in parallel.

7. 2 ducts connected in series ( 5 sets) and 2 ducts having 3 and 2 PV modules, all are connected in parallel.

8. 3 ducts connected in series ( 3 sets) and 3 duct having 3, 3 and 2 PV modules, all are connected in parallel.

9. 3 ducts connected in ( 3 sets), 2 ducts connected in series (1set) and one duct having 2 PV modules, all are connected in parallel.

10. 4 ducts connected in series (2 sets), 2 duct connected in series (1set), 1 duct and 1 duct having 2 PV modules, all are connected in parallel.

11. 4 ducts connected in series (2 sets), 3 ducts connected in series ( 1 set) and 1 duct having $2 \mathrm{PV}$ modules, all are connected in parallel.

12. 5, 4, 1 and 1 ducts (1 set each) and 1 duct having 2 PV modules, all are connected in parallel.

13. 5, 4 and 2 ducts (1set each) and 1 duct having $2 \mathrm{PV}$ modules, all are connected in parallel.

14. 5 ducts connected in series (2 sets), 1 duct and 1 duct having $2 \mathrm{PV}$ modules, all are connected in parallel.

Performance of BIPV system for Indian weather conditions have been evaluated by considering four weather conditions for five different cities (New Delhi, Bangalore, Mumbai, Srinagar, and Jodhpur) of India. These cities are classified under the five different climatic condition of India. The four type of weather conditions are defined as,

Type a: The ratio of daily diffuse to daily global radiation is less than or equal to 0.25 and sunshine hours greater than or equal to 9 hours.

Type b: The ratio of daily diffuse to daily global radiation between 0.25 to 0.50 and sunshine hours between 7 to 9 hours. 
Type c: The ratio of daily diffuse to daily global radiation between 0.50 to 0.75 and sunshine hours between 5 to 7 hours.

Type d: The ratio of daily diffuse to daily global radiation is greater than or equal to 0.75 and sunshine hours less than or equal to 5 hours.

Data of solar radiations for different climates are obtained from Indian Meteorological Department (IMD), Pune. The glass to tedlar type PV module is manufactured by Central Electronics Ltd. (CEL) Sahibabad, Ghaziabad (U.P.).

\section{THERMAL MODELING}

In order to write the energy balance equation for each component of $\mathrm{PV} / \mathrm{T}$ air heater, following assumptions has been made:

- The system is in quasi-steady state.

- Transitivity of EVA is approximately $100 \%$.

- Temperature variation along thickness as well as width is negligible.

- Air flow between the tedlar and wood structure is uniform for forced mode of operation.

Following Tiwari et al. [15], the energy balance equation of hybrid PV/thermal system is as follows (Fig. 1c),

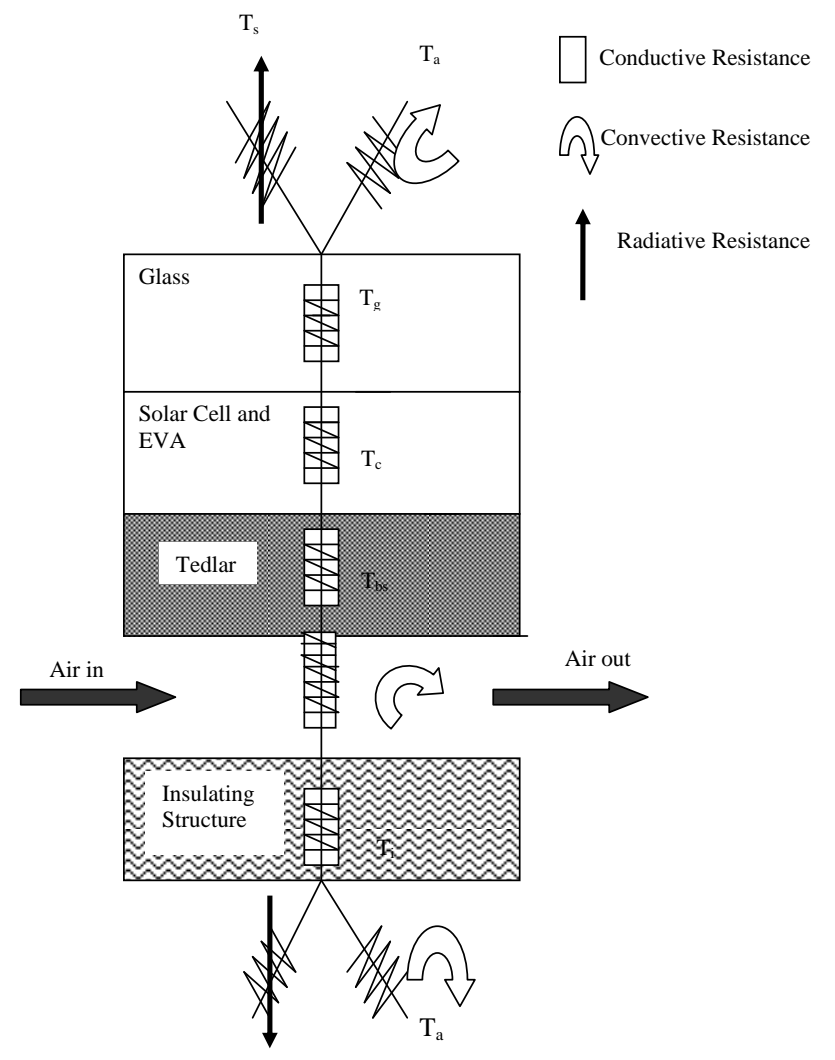

Fig. (1c). Thermal resistance circuit diagram for unglazed PV/Thermal air with tedlar.

\section{(i) For PV module:}

$\tau_{G}\left[\alpha_{c} I(t) \beta_{c}+\left(1-\beta_{c}\right) \alpha_{T} I(t)\right] b d x=\left[U_{t}\left(T_{c}-T_{a}\right)+U_{T}\left(T_{c}-T_{b s}\right)\right] b d x+\eta_{c} I(t) \beta_{c} b d x$ (ii) For back surface of tedlar:

$U_{T}\left(T_{c}-T_{b s}\right) b d x=h_{T}\left(T_{b s}-T_{a i r}\right) b d x$

(iii) For air flowing below tedlar:

$$
h_{T}\left(T_{b s}-T_{a i r}\right) b d x=\dot{m}_{a} c_{a} \frac{d T_{\text {air }}}{d x} d x+U_{b}\left(T_{\text {air }}-T_{a}\right) b d x
$$

Using Eq. (1) and (2) the Eq. (3) can be written as,

$b\left[h_{p 1} h_{p 2}(\alpha \tau)_{e f f} I(t)\right]=\dot{m}_{a} c_{a} \frac{d T_{a i r}}{d x}+b U_{L}\left(T_{a i r}-T_{a}\right)$

where $U_{L}=U_{\text {Tair }}+U_{b}, \quad h_{p 1}=\frac{U_{T}}{U_{t}+U_{T}}, \quad h_{P 2}=\frac{h_{T}}{U_{t T}+h_{T}}$

Integrating Eq. (4) with initial condition at $\mathrm{x}=0, \mathrm{~T}_{\text {air }}=$ $\mathrm{T}_{\text {airin, }}$ we get

$T_{a i r}=\frac{h_{p 1} h_{p 2}(\alpha \tau)_{e f f} I(t)}{U_{L}}\left(1-e^{-b U_{L} x / m_{a} c_{a}}\right)+T_{a}\left(1-e^{-b U_{L} x / m_{a} c_{a}}\right)+$

$\cdot T_{\text {airin }} e^{-b U_{l} x / m_{a} c_{a}}$

Now, the outlet air temperature $\left(\mathrm{T}_{\text {airout }}\right)$ can be obtained from above equation as

$$
\begin{aligned}
& T_{\text {airout }}=T_{\text {air }}(a t x=L)=\left[\frac{h_{p 1} h_{p 2}(\alpha \tau)_{e f f} I(t)}{U_{L}}+T_{a}\right]\left(1-e^{-b U_{L} L / \dot{m}_{a} c_{a}}\right)+ \\
& T_{\text {airin }} e^{-b U_{L} L \dot{m}_{a} c_{a}} \\
& T_{b s}=\frac{h_{p 1}(\alpha \tau)_{e f f} I(t)+U_{t T} T_{a}+h_{T} T_{\text {air }}}{U_{t T}+h_{T}} \\
& T_{c}=\frac{\left[\alpha_{c} \beta_{c}+\alpha_{T}\left(1-\beta_{c}\right)\right] I(t)-\eta_{c} I(t) \beta_{c}+U_{t} T_{a}+U_{T} T_{b s}}{U_{t}+U_{T}}
\end{aligned}
$$

The average air temperature over the length of air duct below PV module is

$$
\begin{aligned}
& T_{\text {avg }}=\frac{1}{L} \int_{0}^{L} T_{\text {air }} d x=\left[\frac{h_{p 1} h_{p 2}(\alpha \tau)_{e f f} I(t)}{U_{L}}+T_{a}\right]\left(1-\frac{1-e^{-b U_{L} L / \dot{m}_{a} c_{a}}}{b U_{L} / \dot{m}_{a} c_{a}}\right)+ \\
& T_{\text {airin }} e^{-b U_{L} L / \dot{m}_{a} c_{a}}
\end{aligned}
$$

The rate of useful thermal energy obtained from $\mathrm{PV} / \mathrm{T}$ system is

$$
\begin{aligned}
q_{u} & =\dot{m}_{a} c_{a}\left(T_{\text {airout }}-T_{\text {airin }}\right) \\
& =\frac{\dot{m}_{a} c_{a}}{U_{L}}\left[h_{p 1} h_{p 2}(\alpha \tau)_{e f f} I(t)-U_{L}\left(T_{\text {airin }}-T_{a}\right)\right]\left(1-e^{-b U_{L} L / \dot{m}_{a} c_{a}}\right)
\end{aligned}
$$

The net electrical energy gain is defined as 
Table 1. Design Parameters for Integrated Photovoltaic Thermal System

\begin{tabular}{|c|c|}
\hline Parameters & Values \\
\hline \hline $\mathrm{A}$ & $0.6 \mathrm{~m}^{2}$ \\
$\mathrm{~b}$ & $0.5 \mathrm{~m}$ \\
$\mathrm{~h}_{\mathrm{p} 1}$ & 0.899 \\
$\mathrm{~h}_{\mathrm{p} 2}$ & 0.54 \\
$\mathrm{~K}_{\mathrm{c}}$ & $0.039 \mathrm{~W} / \mathrm{m} \mathrm{K}$ \\
$\mathrm{K}_{\mathrm{G}}$ & $1.0 \mathrm{~W} / \mathrm{m} \mathrm{K}$ \\
$\mathrm{K}_{\mathrm{T}}$ & $0.033 \mathrm{~W} / \mathrm{m} \mathrm{K}$ \\
$\mathrm{L}$ & $1.2 \mathrm{~m}$ \\
$\mathrm{~L}_{\mathrm{c}}$ & $0.0003 \mathrm{~m}$ \\
$\mathrm{~L}_{\mathrm{G}}$ & $0.003 \mathrm{~m}$ \\
$\mathrm{~L}_{\mathrm{T}}$ & $0.0005 \mathrm{~m}$ \\
$\mathrm{U}_{\mathrm{b}}$ & $0.62 \mathrm{~W} / \mathrm{m}^{2} \mathrm{~K}$ \\
$\mathrm{U}_{\mathrm{t}}$ & $7.45 \mathrm{~W} / \mathrm{m}^{2} \mathrm{~K}$ \\
$\mathrm{U}_{\mathrm{T}}$ & $66.6 \mathrm{~W} / \mathrm{m}^{2} \mathrm{~K}$ \\
$\mathrm{U}_{\mathrm{tT}}$ & $6.7 \mathrm{~W} / \mathrm{m}^{2} \mathrm{~K}$ \\
$\alpha_{\mathrm{c}}$ & 0.90 \\
$\alpha_{\mathrm{T}}$ & 0.50 \\
$\beta_{\mathrm{c}}$ & 0.83 \\
$\eta_{\mathrm{c}}$ & 0.12 \\
$\tau_{\mathrm{G}}$ & 0.95 \\
\hline & \\
\hline
\end{tabular}

$\dot{Q}_{u, \text { net electrical }}=$ Power generated by PV $\bmod$ ules - Power consumed by fan

or, $\dot{Q}_{u, \text { net electrical }}=\eta_{c} \times A_{d} \times N_{d} \times I(t)-P_{\text {con, fan }}$

In addition to the above equations the relations used for defining the design parameters are given in Table $\mathbf{1}$.

\section{RESULT AND DISCUSSION}

The data obtained from Indian Meteorological Department (IMD), Pune is used for calculating the solar radiation on all facades of the building using Liu and Jordan formula [16]. The hourly variation of beam and total radiation for a typical day in the summer month (May) for New Delhi condition is shown in Figs. (2). The beam radiation is zero on east and west facade (inclined at $90^{\circ}$ ) during evening and morning hours respectively, as expected. Beam radiation on south façade (inclined at $90^{\circ}$ ) at $8 \mathrm{am}, 4 \mathrm{pm}$ and $5 \mathrm{pm}$ are also zero due to the overhead motion of the sun. Hourly variation of power output from roof (inclined at $30^{\circ}$ ), south, east and west facades are shown in Fig. (3). Maximum power output is obtained for inclined roof.

Eq. (7) has been used for calculating the average outlet air temperature over the length of duct. Series connection of seven ducts each is having five PV modules (35 modules) is shown in Fig. (4). Hourly variation of outlet air temperature by varying the number of ducts connected in series is shown in Fig. (5a). Outlet air temperature increases from $45.5^{\circ} \mathrm{C}$ to $89.7^{\circ} \mathrm{C}$ as the number of duct increases from 1 to 7 . Simi-

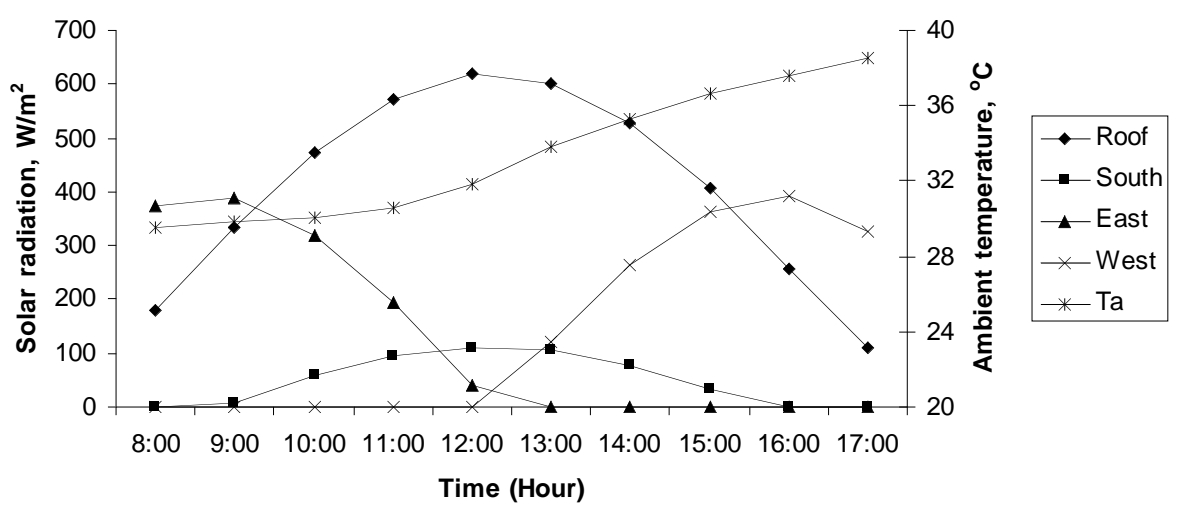

Fig. (2a). Hourly variation of beam radiation on roof (inclined), South, East and West facades for a typical day of summer (May) month (New Delhi condition).

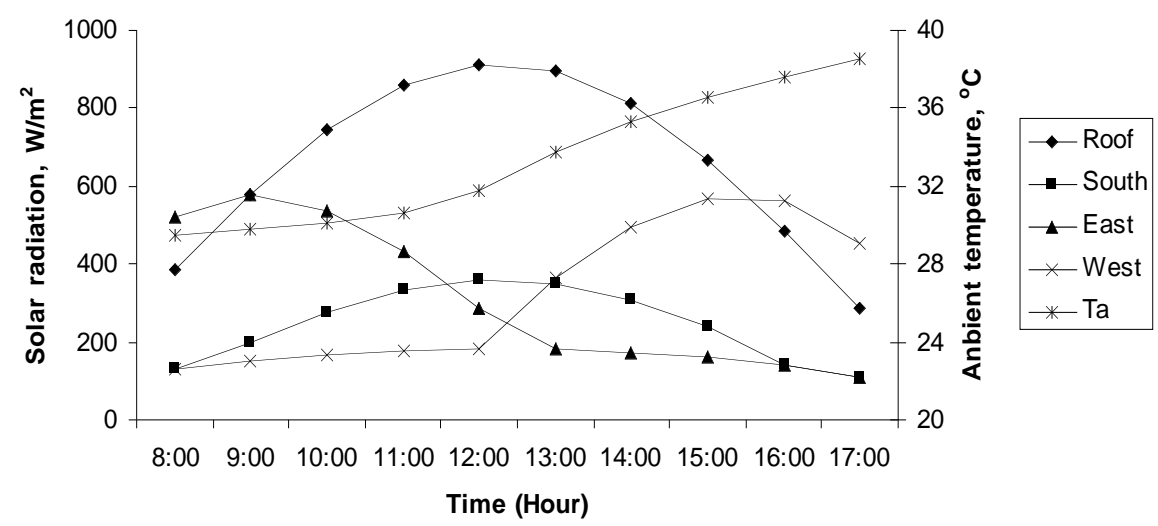

Fig. (2b). Hourly variation of total radiation on roof (inclined), South, East and West facades for a typical day of summer (May) month (New Delhi condition). 


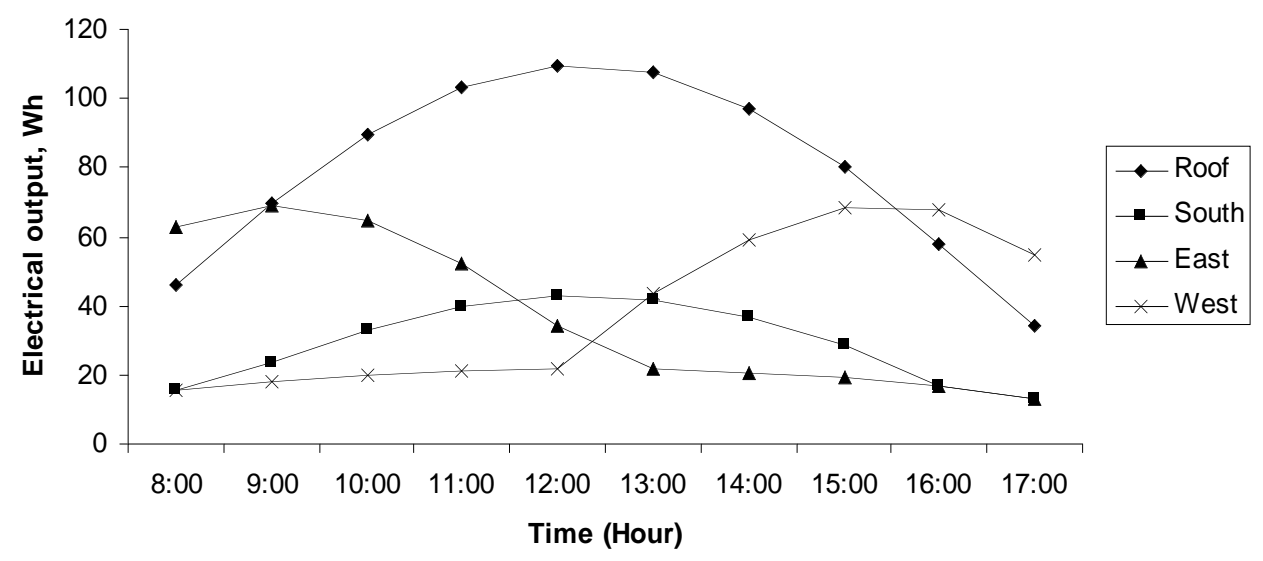

Fig. (3). Hourly variation of power output from roof (inclined), South, East and West facades for a typical day of summer (May) month (New Delhi condition).

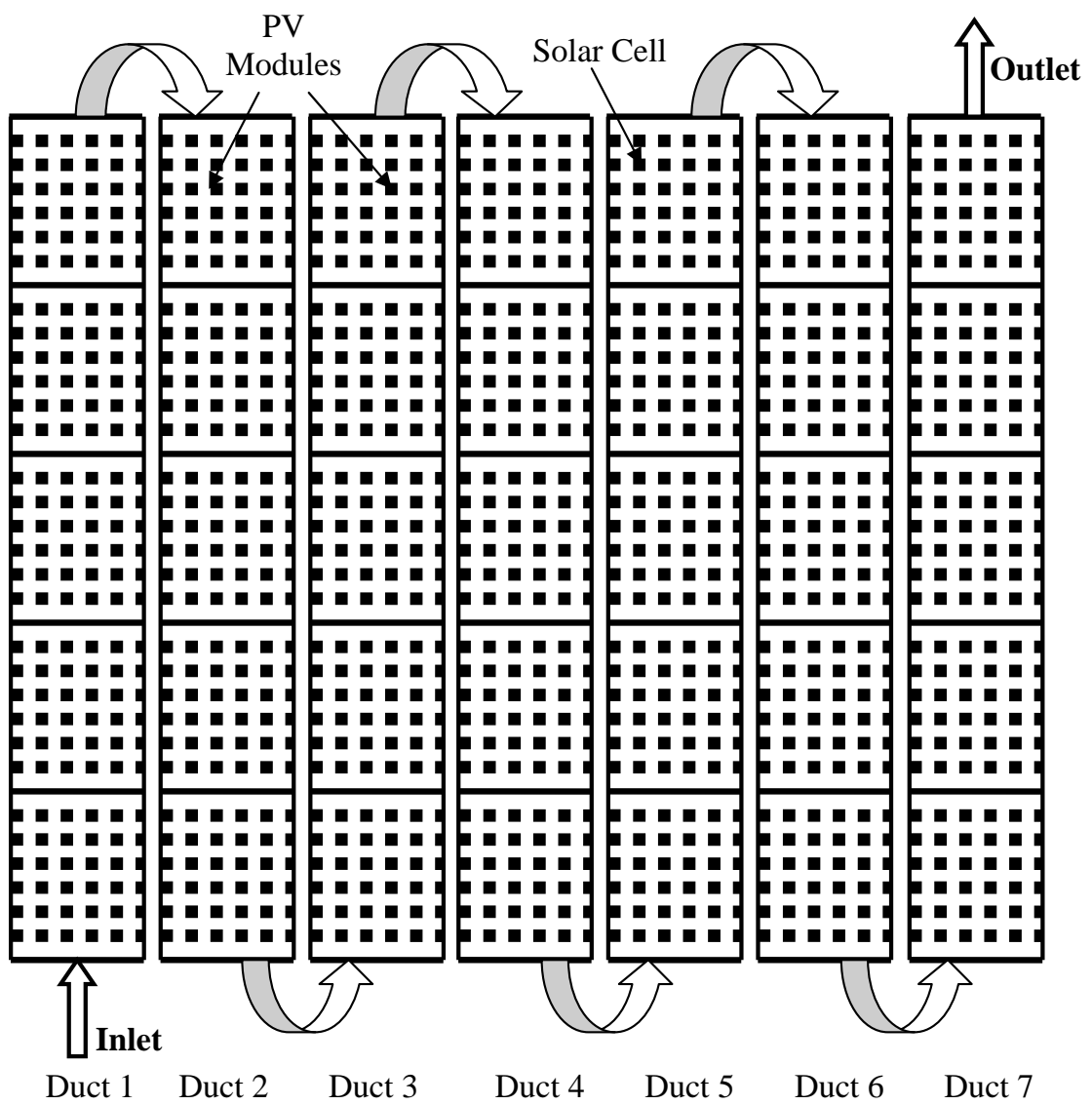

Fig. (4). Series connection of seven ducts each is having five PV modules (35 modules).

larly, Eq. (8) has been used for calculating the useful heat gain, the variation is shown in Fig. (5b). Useful heat gain increases from $0.62 \mathrm{kWh}$ to $3.48 \mathrm{kWh}$ as the number of duct increases from 1 to 7 . Hourly variation of outlet air temperature for different air velocities considering seven ducts connected in series is shown in Fig. (6).

Hourly variations of solar cell temperature and electrical efficiency with and without duct are shown in Fig. (7). Figure shows that due to the increase in cell temperature cell efficiency decreases. In the case of 'with duct' heat is re- moved from back surface of the module which decreases the solar cell temperature and increases the solar cell efficiency.

Variation of annual thermal and electrical gain from different combinations of air duct considering the four types (a, b, c, and d) of weather condition of New Delhi (air velocity in duct is $2 \mathrm{~m} / \mathrm{sec}$ ) is shown in Fig. (8). Maximum thermal (13.42 MWh) and electrical (4.38 MWh) gain is obtained for sixth combination (11 ducts connected in parallel (1 set) and one duct having 2 PV module, all are connected in parallel) because in parallel connection outlet air temperature is low 


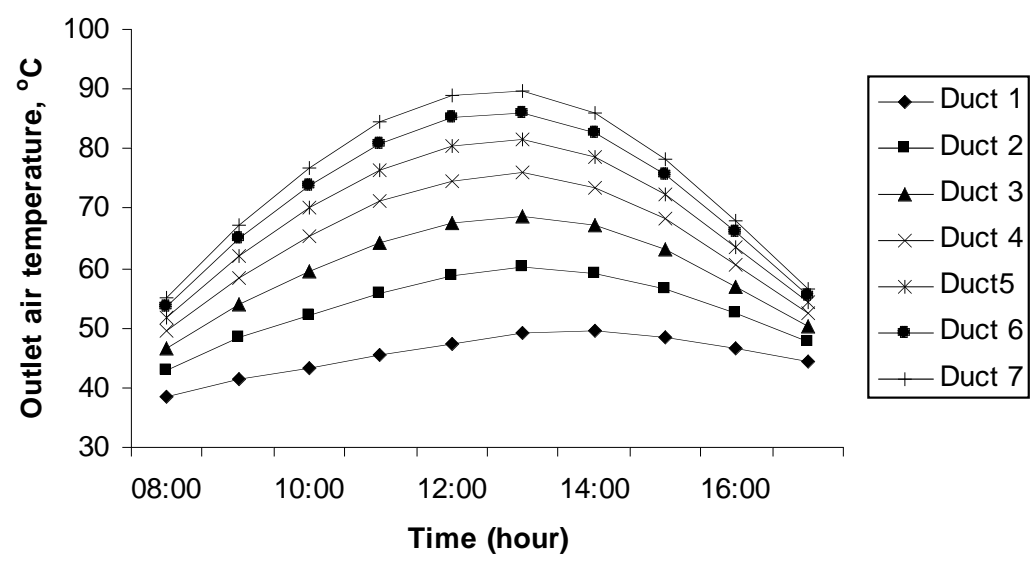

Fig. (5a). Hourly variation of outlet air temperature with no. of duct connected in series for a typical day of summer (May) month (New Delhi condition).

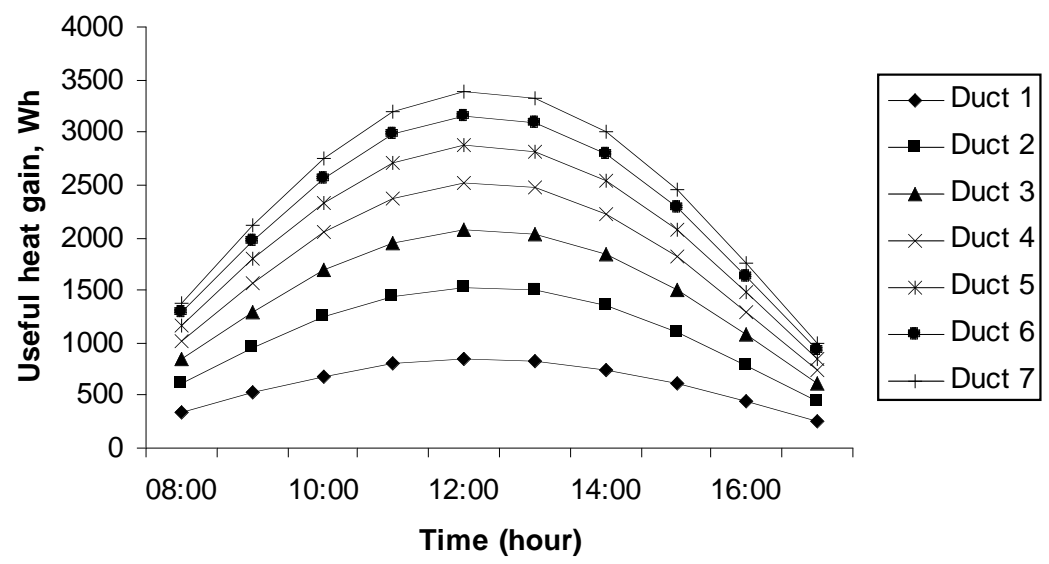

Fig. (5b). Hourly variation of useful thermal gain with no. of duct connected in series for a typical day of summer (May) month (New Delhi condition).

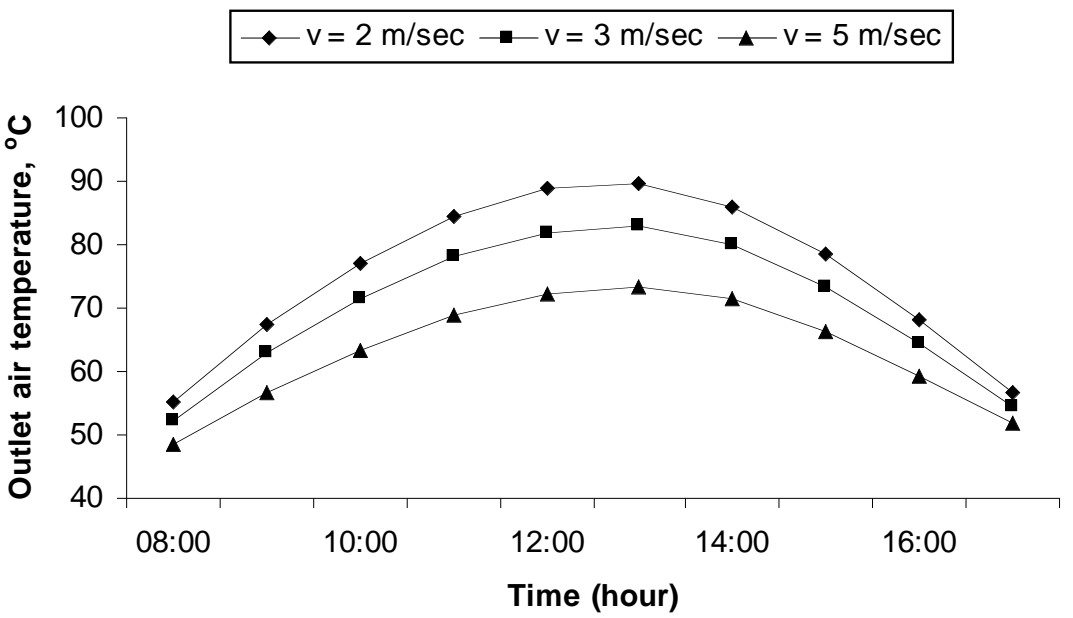

Fig. (6). Hourly variation of outlet air temperature for different air velocities in duct, when seven ducts are connected in series.

and losses are less. Monthly variation of thermal and electrical gain for New Delhi condition is shown in Fig. (9a and 9b). Maximum and minimum gain is obtained in May and February month respectively. Monthly variation of average electrical efficiency for sixth combination is shown in Fig. (9c), annual average is $9.64 \%$.
Annual variation of thermal and electrical gain for five climatic conditions of India (New Delhi, Bangalore, Mumbai, Srinagar, and Jodhpur) considering four weather conditions for sixth combination is shown in Fig. (10). Maximum thermal energy gain is obtained for Jodhpur city however maximum electrical energy gain is obtained for Bangalore 

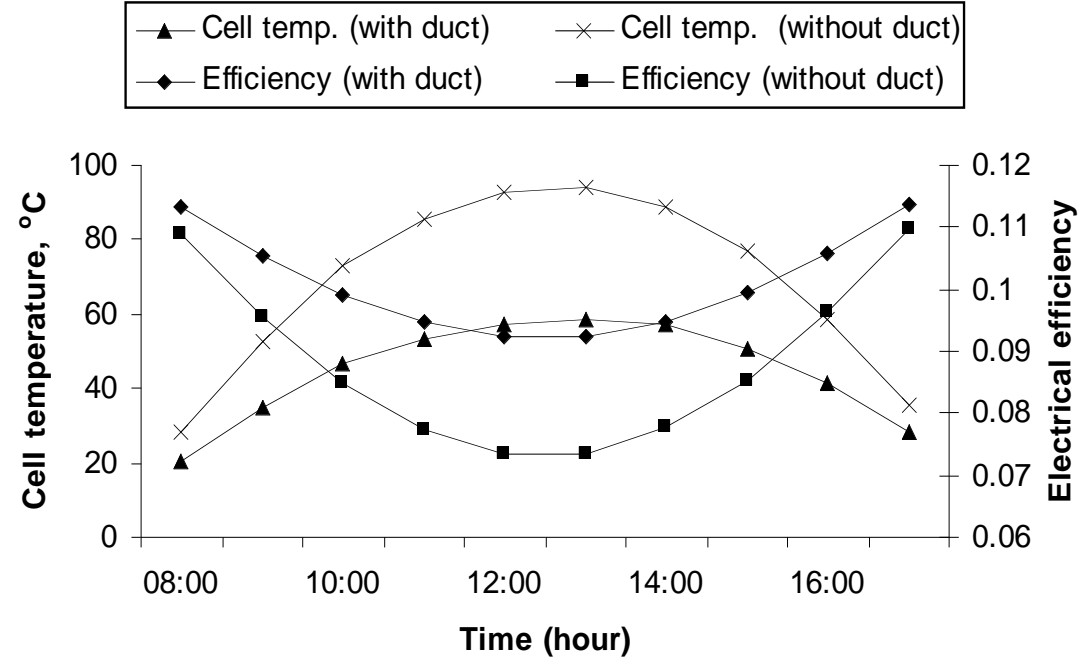

Fig. (7). Hourly variations of cell temperature and electrical efficiency with and without duct.

$\square$ Thermal gain $\square$ Electrical gain

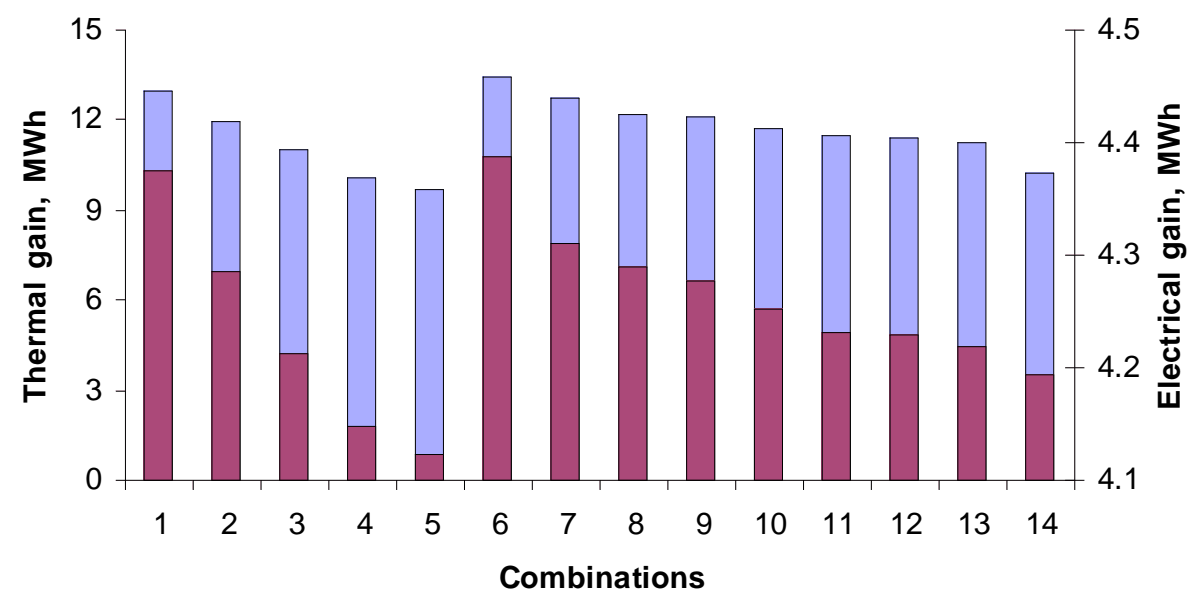

Fig. (8). Variation of annual thermal and electrical gain from different combinations of air duct for New Delhi condition, air velocity in duct is $2 \mathrm{~m} / \mathrm{sec}$.

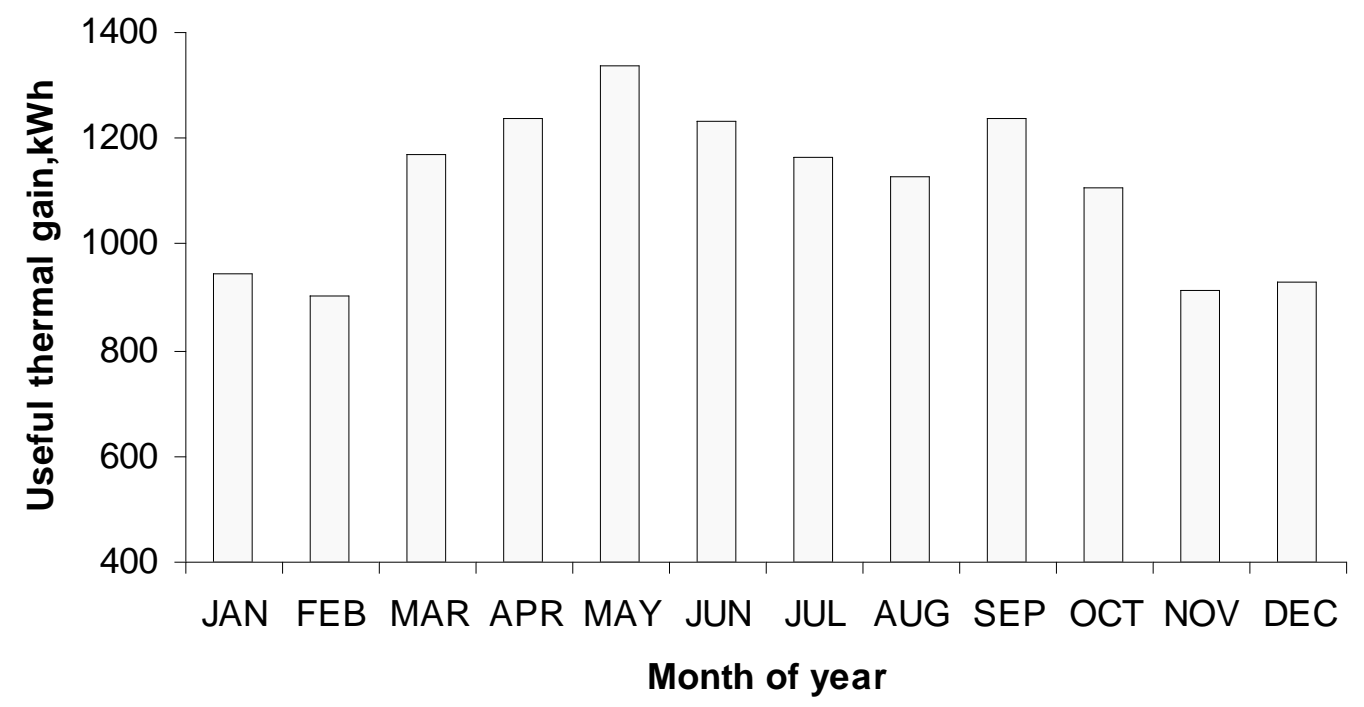

Fig. (9a). Monthly variation of useful thermal gain for sixth combination (New Delhi). 


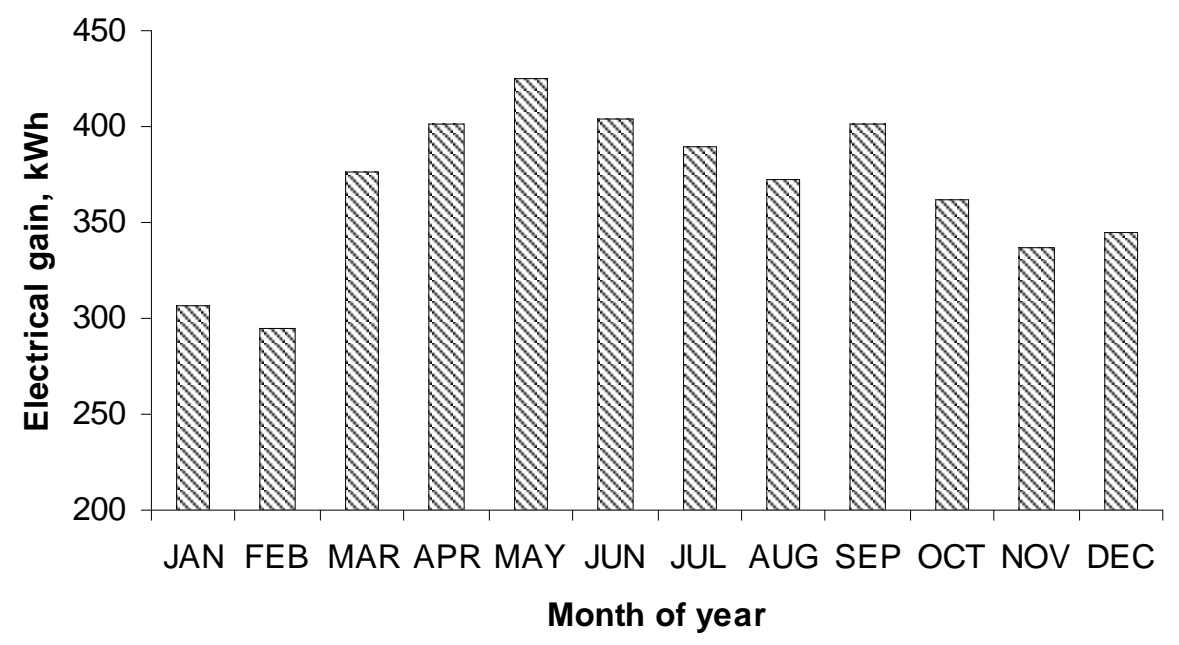

Fig. (9b). Monthly variation of electrical gain for sixth combination (New Delhi).

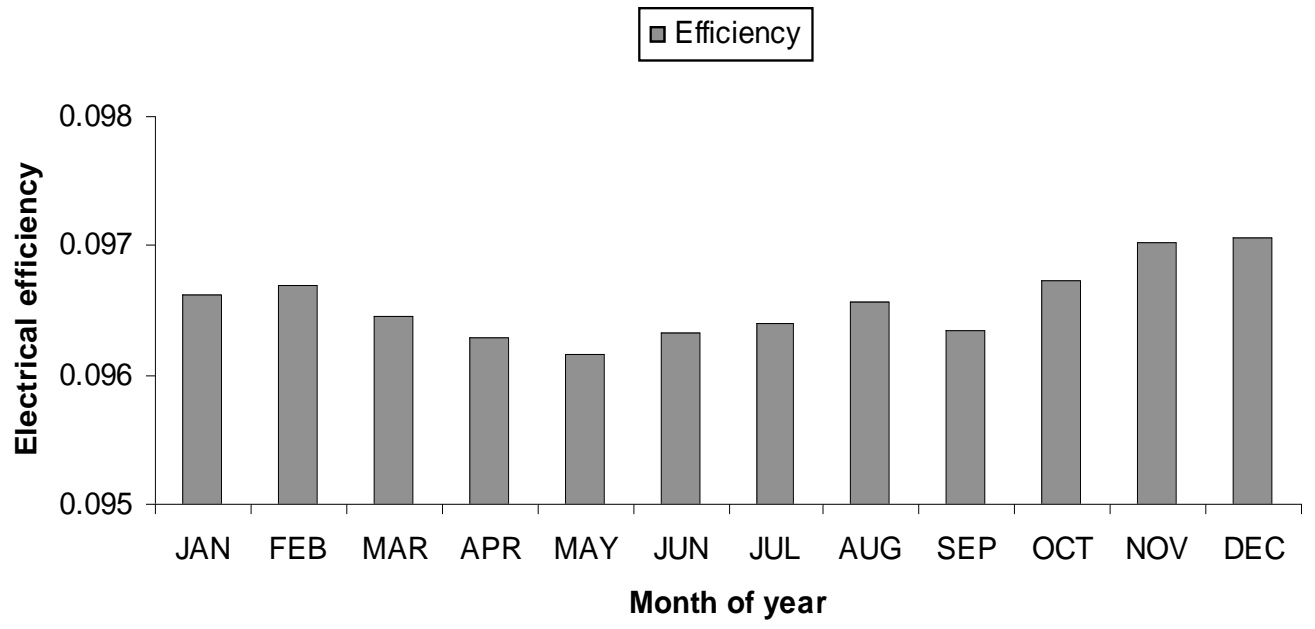

Fig. (9c). Monthly variation of average electrical efficiency for sixth combination (New Delhi).

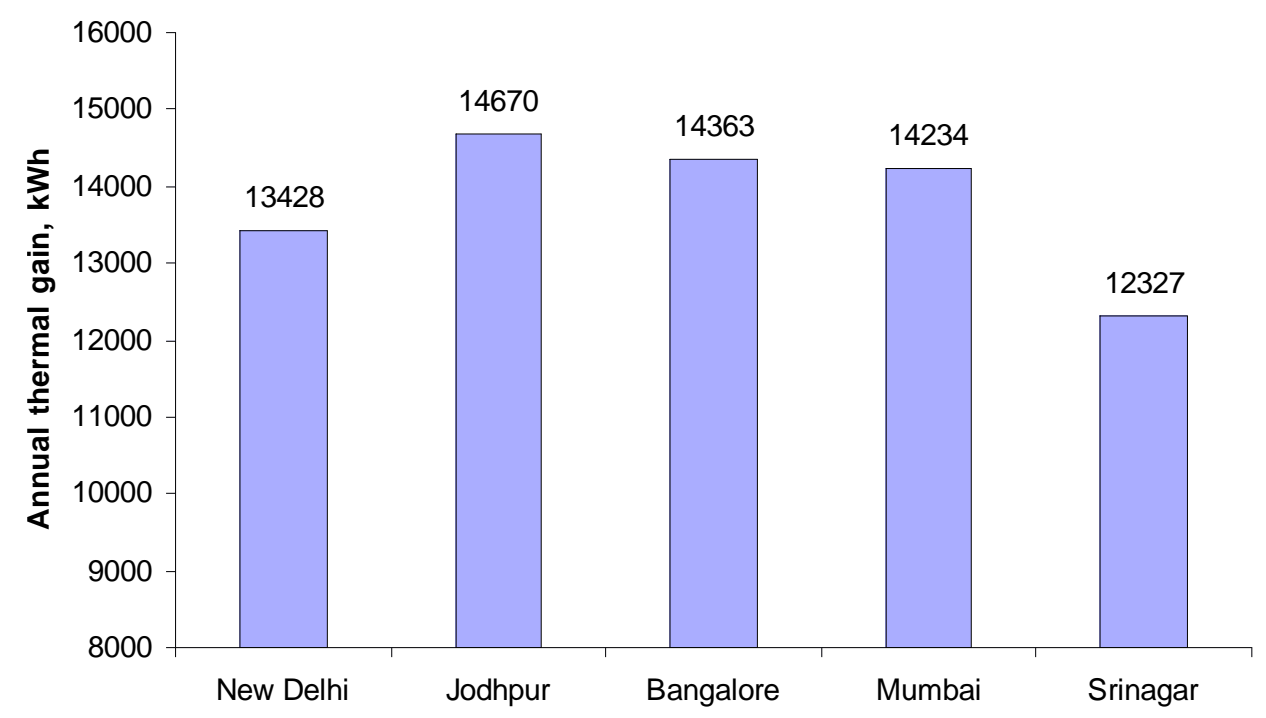

Fig. (10a). Annual variation of thermal gain for five climatic conditions of India by considering sixth combination. 


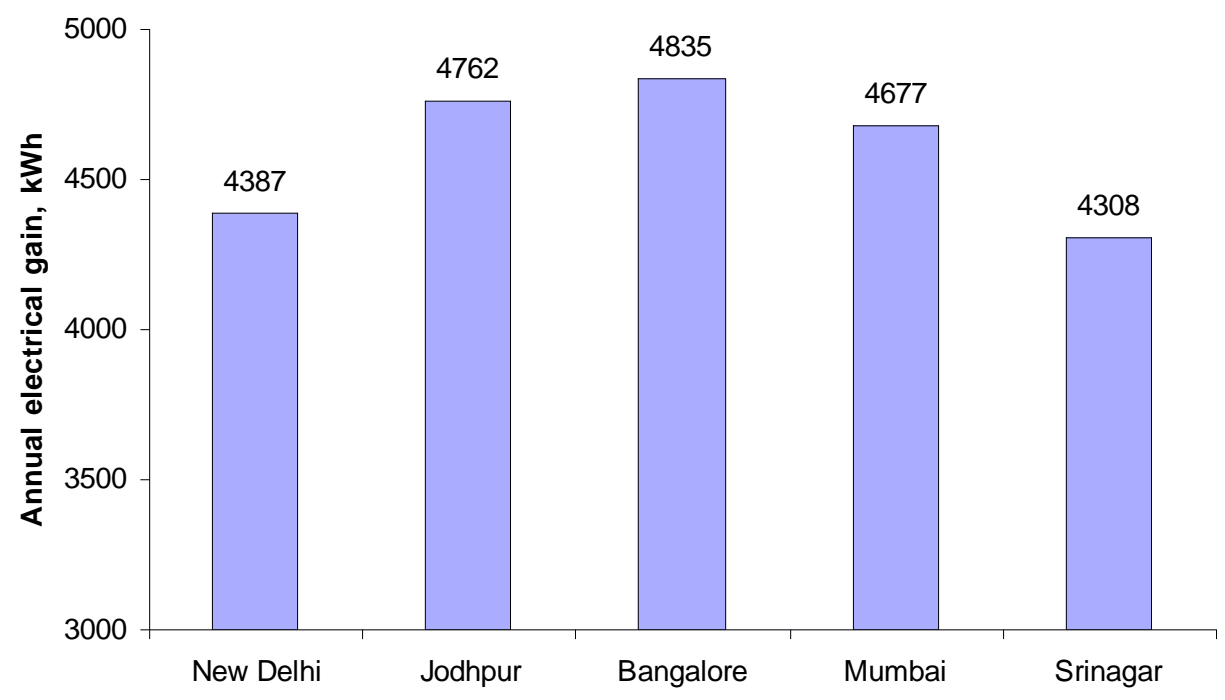

Fig. (10b). Annual variation of electrical gain for five climatic conditions of India by considering sixth combination.

city due to the lower annual ambient temperature. Minimum thermal and electrical energy gain is obtained for Srinagar city due to less availability of solar radiation. The percentage variation between Jodhpur and Srinagar city is $15.9 \%$. and $9.5 \%$ for thermal and electrical energy gain respectively. The percentage variation between New Delhi, Mumbai and Bangalore with Srinagar are $8.1 \%, 13.3 \%$ and $14.1 \%$ on thermal basis and $1.8 \%, 7.8 \%$ and $10.8 \%$ on electrical basis respectively.

\section{CONCLUSION}

In this paper, electrical and thermal performance of existing grid connected building integrated photovoltaic system (BIPV) has been evaluated for Indian climatic condition. Fourteen different possible combinations are studied for calculation of thermal and electrical gain. Results show that the sixth combination gives maximum thermal and electrical gain. Depending upon users' requirement, higher outlet air temperature is used for drying purpose and higher heat gain is used for space heating. The average electrical efficiency of the system is found to be $9.64 \%$.

This is a self sustainable system and can be installed in urban or rural areas for electricity generation. The thermal energy generated by the system can be used for space heating or drying purpose. It plays a very important role in education and deployment of renewable energy application in India and beneficial in terms of energy security of country.

\section{NOMENCLATURE}
A $=$ Area $\left(\mathrm{m}^{2}\right)$
$\mathrm{b}=\operatorname{Breadth}(\mathrm{m})$
$\mathrm{C}=$ Specific heat $\left(\mathrm{kJ} \mathrm{kg}^{-1} \mathrm{~K}^{-1}\right)$
$\mathrm{dx}=$ Elementary length $(\mathrm{m})$
$\mathrm{h}=$ Heat transfer coefficient $\left(\mathrm{W} \mathrm{m}^{-2} \mathrm{~K}^{-1}\right)$
$\mathrm{h}_{\mathrm{p} 1}=$ Penalty factor due to presence of glass on solar cell (dimensionless)

$\mathrm{h}_{\mathrm{p} 2}=$ Penalty factor due to presence of interface between tedlar and working fluid (dimensionless)

$\mathrm{I}(\mathrm{t})=$ Incident solar intensity $\left(\mathrm{W} \mathrm{m}^{-2}\right)$

$\mathrm{L}=$ Length of $\operatorname{duct}(\mathrm{m})$

$\dot{m}_{a}=$ Rate of flow of air mass $\left(\mathrm{kg} \mathrm{s}^{-1}\right)$

$\mathrm{N}=$ Number (dimensionless)

$\dot{Q}_{u}=$ Rate of useful energy transfer $(\mathrm{W})$

$\mathrm{T}=$ Temperature $\left({ }^{\circ} \mathrm{C}\right)$

$\mathrm{U}_{\mathrm{b}}=$ An overall heat transfer coefficient from bottom to ambient $\left(\mathrm{W} \mathrm{m}^{-2} \mathrm{~K}^{-1}\right)$

$\mathrm{U}_{\mathrm{L}}=$ An overall heat transfer coefficient from solar cell to ambient through top and back surface of insulation $\left(\mathrm{W} \mathrm{m} \mathrm{m}^{-2} \mathrm{~K}^{-1}\right)$

$\mathrm{U}_{\mathrm{t}}=$ An overall heat transfer coefficient from solar cell to ambient trough glass cover $\left(\mathrm{W} \mathrm{m}^{-2} \mathrm{~K}^{-1}\right)$

$\mathrm{U}_{\mathrm{tT}}=$ An overall heat transfer coefficient from glass to tedlar through solar cell $\left(\mathrm{W} \mathrm{m}{ }^{-2} \mathrm{~K}^{-1}\right)$

\section{SUBSCRIPTS}

$\begin{array}{lll}\mathrm{a} & = & \text { Ambient } \\ \mathrm{bs} & = & \text { Back surface of tedlar } \\ \mathrm{c} & = & \text { Solar cell } \\ \mathrm{d} & = & \text { Duct area } \\ \text { eff } & = & \text { Effective } \\ \mathrm{f}_{\mathrm{i}} & = & \text { Inlet fluid } \\ \mathrm{f}_{\text {out }} & = & \text { Outlet fluid } \\ \mathrm{G} & = & \text { Glass } \\ \mathrm{T} & = & \text { Tedlar }\end{array}$

\section{GREEK LETTERS}

$\begin{array}{lll}\beta & = & \text { Packing factor } \\ \alpha & = & \text { Absorptivity }\end{array}$


$\eta \quad=\quad$ Efficiency

$\tau=$ Transimitivity

\section{REFERENCES}

[1] Loferski, J.J.; Ahmad, J.M.; Pandey, A. Performance of photovoltaic cells incorporated into unique hybrid photovoltaic/thermal panels of a $2.8 \mathrm{KW}$ residential solar energy conversion system, In Proc. of the 1988 Annual Meeting, American Solar Energy Society, Cambridge, Massachusetts, 1988; pp. 427-432.

[2] Bhargava, A.K.; Garg, H.P.; Agarwal, R.K. Study of a hybrid solar system - solar air heater combined with solar cells. Energ. Convers. Manag., 1991, 31, 471-479.

[3] Prakash, J. Transient analysis of a photovoltaic-thermal solar collector for co-generation of electricity and hot air/ water. Energ. Convers. Manag., 1994, 35, 967-972.

[4] Brinkworth, B.J.; Cross, B.M.; Marshall, R.H.; Yang, H. Thermal regulation of photovoltaic cladding. Sol. Energ., 1997, 61, 169-178.

[5] Hegazy, A.A. Comparative study of the performance of four photovoltaic / thermal solar air collectors. Energ. Convers. Manag., 2000, 41 (8), 861-881.

[6] Sopian, K.; Liu, H.T.; Kakac, S.; Veriroglu, T.N. Performance of a double pass photovoltaic thermal solar collector suitable for solar drying systems. Energ. Convers. Manag., 2000, 41(4), 353-365.

[7] Tripanagnostopoulos, Y.; Nousia, T.H.; Souliotis, M.; Yianoulis, P. Hybrid photovoltaic / thermal solar system. Sol. Energ., 2002, 72 (3), 217-234.
[8] Murata, K.; Yagiura, T.; Takeda, K.; Tanaka, M.; Kiyama, S. New type of photovoltaic module integrated with roofing material (highly fire-resistant PV tile). Sol. Energ. Mat. Sol. Cells, 2003, 75, 647-653.

[9] Yang, H.; Zheng, G.; Lau, D.; An, J.; Burnett, H. Grid-connected building photovoltaic: a Hong Kong case study. Sol. Energ., 2004, 76, 55-59.

[10] Zakharchenko, R.; Licea-Jime'nez, L.; Pe'rez-Garci'a, S.A.; Vorobiev, P.; Dehesa- Carrasco, U.; Pe'rez-Robels, J.F.; Gonza'lezHerna'ndez, J.; Vorobiev, Y. Photovoltaic solar panel for a hybrid PV/T system. Sol. Energ. Mat. Sol. Cells, 2004, 82 (1-2), 253-261.

[11] Infield, D.; Mei, L.; Eicker, U. Thermal performance estimation of ventilated PV facades. Sol. Energ., 2004, 76 (1-3), 93-98.

[12] Drif, M.; Parez, P.J.; Aguilera, A.; Almonacid, G.; Gomez, P.; De la Casa, J.; Aguilar, J.D. Univer Project. A grid connected photovoltaic system of $200 \mathrm{kWp}$ at Jaen University. Overview performance analysis. Sol. Energ. Mat. Sol. Cells, 2007, 91, 670-683.

[13] Tian, W.; Wang, Y.; Ren, J.; Zhu, L. Effect of urban climate on building integrated photovoltaic performance. Energ. Convers. Manag., 2007, 48, 1-8.

[14] Bloem, J.J. Evaluation of a PV- integrated building application in a well-controlled outdoor test environment. Build. Environ., 2008, 43 (2), 205-216.

[15] Tiwari, A.; Sodha, M.S.; Chandra, A.; Joshi, J.C. Performance evaluation of photovoltaic thermal solar air collector for composite climate of India. Sol. Energ. Mat. Sol. Cells, 2006, 90, 175-189.

[16] Liu, B.Y.H.; Jordan, R.C. Daily insolation on surface tilted towards equator. ASHRAE J., 1962, 3(10), 53.

(C) Ranjan et al.; Licensee Bentham Open.

This is an open access article licensed under the terms of the Creative Commons Attribution Non-Commercial License (http://creativecommons.org/licenses/by-nc/3.0/) which permits unrestricted, non-commercial use, distribution and reproduction in any medium, provided the work is properly cited. 